\title{
Research Focus, Frontier and Knowledge Base of Green Technology in China: Metrological Research Based on Mapping Knowledge Domains
}

\author{
Xingwei Li ${ }^{1 *}$, Hongyu Long² \\ ${ }^{1}$ School of Management, Jiangsu University, Zhenjiang, China \\ ${ }^{2}$ School of Civil Engineering and Architecture, Southwest Petroleum University, Chengdu, China
}

Received: 16 October 2019

Accepted: 21 November 2019

\begin{abstract}
Priority needs to be given to the green technology of saving resources, saving energy and reducing pollution by enterprises in the new era where green development needs promotion because humans and nature are the community of life. In essence, green technology is the innovation-driven development of enterprises under the background of green development. In order to sort out the research trend of Chinese scholars on green technology, 206 articles published during the period of 1994 to 2017 and their citations mainly from the Chinese Social Sciences Citation Index database were studied by means of bibliometrics and mapping knowledge domains, which reveals the trend of a number of Chinese green technology research papers published, the evolution path of the hot research topics, the research frontier and the knowledge base, drawing inspiration from them. The main conclusions are as follows:

1) The number of Chinese scholars' research on green technology shows an N-type upward trend and will continue to rise in the future.

2) Green technology, technological innovation and environmental protection have long been research hotspots of China's green technology research.

3) The frontiers of green technology research in China can be divided into three stages for germination (1994 to 2010), rapid growth (2010 to 2014)and depth advancement (2015 to present.

4) The knowledge base of green technology research in China is mainly composed of efficiency, the relationship between the environment and economics, green technological innovation, environmental regulation and intellectual property.
\end{abstract}

Keywords: technological innovation, green technology, green development, mapping knowledge domains, CiteSpace

*e-mail: 2111710001@stmail.ujs.edu.cn 


\section{Introduction}

Technology is one of the most important production factors of an enterprise, which is not only closely related to corporate performance, but also people's living environment [1-3]. For a long time, most companies have been paying more attention to whether the renewal of technology can bring economic benefits. However, as climate change intensifies, people are increasingly aware that economic development models at the expense of the ecological environment are not advisable. In the report of the 19th National Congress of the Communist Party of China, Xi Jinping, the chairman of the People's Republic of China, pointed out that man and nature are communities of life, and that China needs to adhere to green development [4-6]. Unlike traditional non-green technologies, green technology is a technology that conserves resources and energy consumption while reducing environmental pollution [7-9]. Because of its significant advantages, green technology is widely used in energy, construction, information and other fields, such as green energy technology, green building technology, and green information technology [10-13]. In addition, the cost of green technology will decrease over time [14-15]. Moreover, whether companies adopt green technology has always been of high concern for consumers [16-17]. Therefore, green technology has great potential [18-19]. It can be seen that green technology is of great concern for international scholars. Regardless of scale or quantity, the influence of Chinese companies in the world business community cannot be ignored. Therefore, China's green technology research has also been highly valued by scholars, and many valuable scientific research achievements have been made in this field. What are the ins and outs of green technologies studied by scholars in China? This is an important issue that this article will address.

Based on the above, this paper gives a study on the visualization of green technology in China that mainly uses the bibliometrics and mapping knowledge domains (MKD) research methods to record 206 articles (published in 1994 to 2017) and their citations which are included in the Chinese Social Sciences Citation Index (CSSCI). This paper reveals the trends of literature volume of green technology research in China, the evolution path of research hotspots, research frontiers and knowledge bases, drawing inspiration from them to provide scientific evidence for relevant research.

\section{Material and Methods}

The research methods used in this paper are bibliometrics and MKD. Bibliometrics, a method of quantitative research on literature, originated in the early 20th century [20-21]. Due to the scientific nature of the analysis process, bibliometrics are widely used in analyzing a particular field of research, main content and recent development [5, 22-23]. This paper mainly uses the bibliometric method to study the annual distribution characteristics of green technology research in China. The MKD research method can perform visual analysis on a certain research field, which is realized by means of data mining, scientific measurement, information analysis and drawing [24]. CiteSpace is a visual analysis software mainly developed for MKD research by Professor Chen of Drexel University in the United States [25], which has been iteratively updated to version 5.2.R2. In this paper, CiteSpace5.2.R2 software is used for the visual analysis of the co-occurrence network and cited cases, obtaining the relevant MKD.

The data for this paper are mainly culled from the CSSCI database. To achieve the purposes of this paper, we are committed to exploring the mapping knowledge domains associated with "green technology". Due to a concerted effort to improve the accuracy of derived results, we limited the document type of this analysis to article and the time span to the last decade (19982017), initially obtaining 198 results retrieved from the previously mentioned database. Next, the China National Knowledge Infrastructure (CNKI) database was used to assist with data collection in order to obtain a more comprehensive data sample since the earliest statistical year data in the CSSCI database is 1998. Using an advanced search function, we limited the title to "green technology" and the time span until 1997, obtaining 14 results. And then 8 valid articles were manually deleted within CSSCI database. Finally, the full bibliographic record from all of the retrieved articles, in total 206, were extracted from the corresponding database according to the export format of the CSSCI database. Therefore, the final data sample for the analysis was 206 papers published in 1994 to 2017 and their citations.

\section{Results and Discussion}

Temporal distribution characteristics

This paper applies Excel software to calculate the annual published volume of 206 articles. Figure 1 shows the trend map of the annual published papers of green technology research in China. Fitting the trend of the published volume, Formula (1) gives the fitting curve of the published quantity of the literature:

$$
\begin{aligned}
& y=-8.5211 x^{6}+0.0006 x^{5}-0.0142 x^{4}+0.15 x^{3}-0.6866 x^{2}+1.9845 x-0.2171 \\
& R^{2}=0.893
\end{aligned}
$$

...where $\mathrm{y}$ is the number of documents and $\mathrm{x}$ is the year. $\mathrm{R}^{2}$ is 0.893 , indicating a good degree of fit. It can be seen that the number of Chinese scholars' research on green technology research shows an N-type upward trend, especially in 2016 and 2017, and the number of documents related to green technology is expected to continue to rise (Fig. 1). 


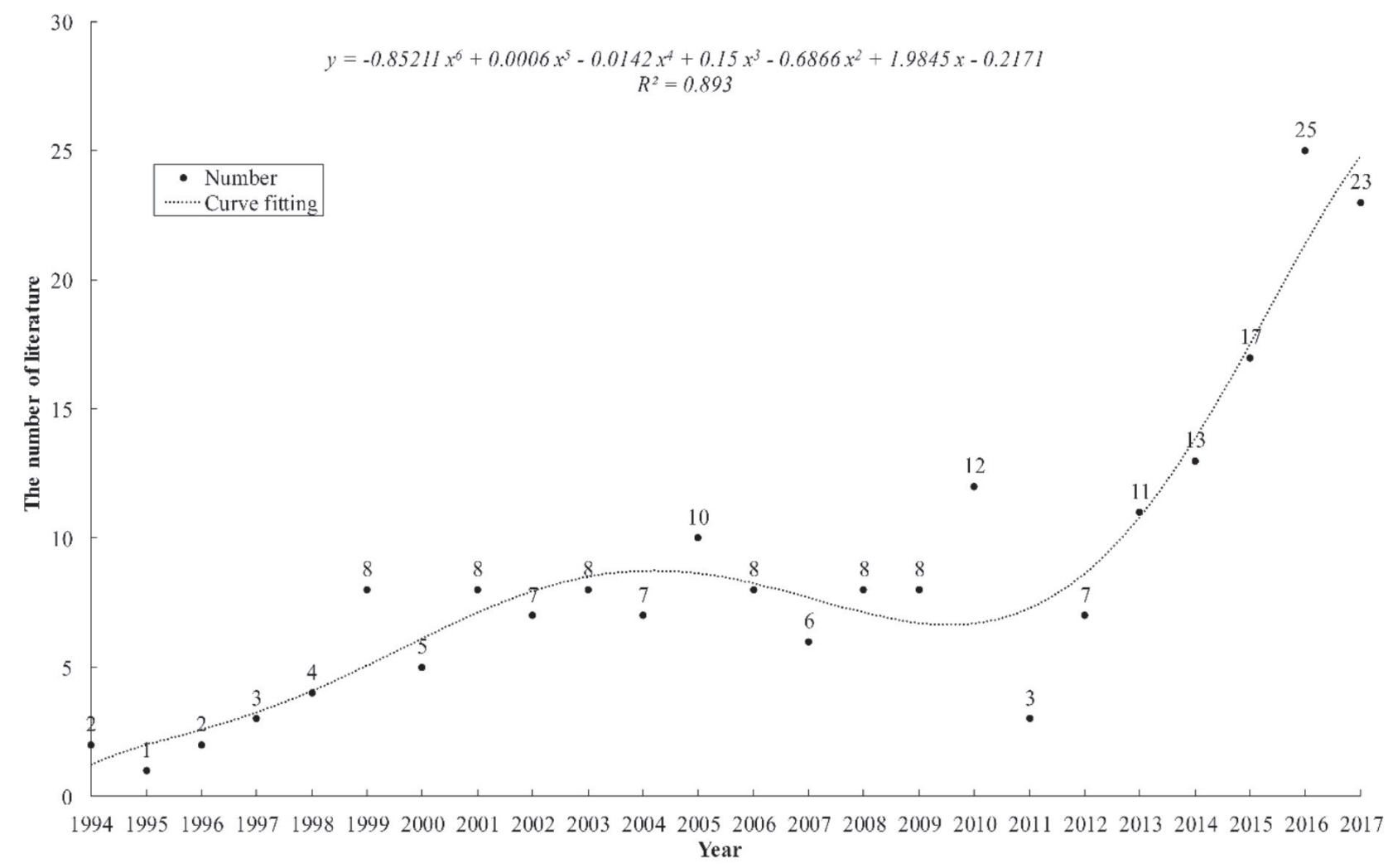

Fig. 1. Trend map of the annual published papers of green technology research in China.

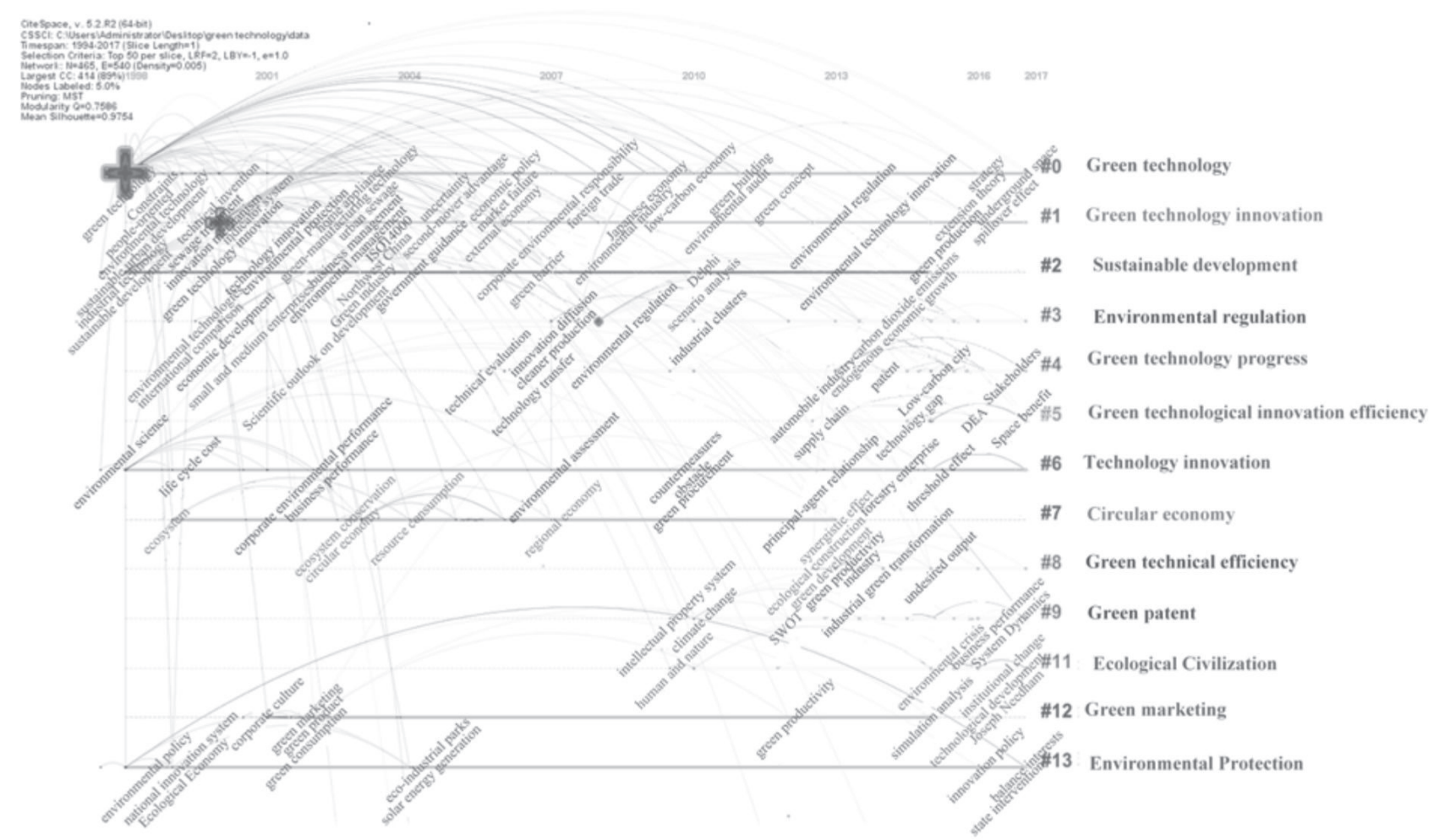

Fig. 2. Knowledge map of the green technology research keyword co-occurrence timeline in China. 


\section{Evolutionary Path of Research Hotspots}

In order to clarify the evolutionary path of green technology research hotspots in China, we used the cooccurrence network analysis function of CiteSpace5.2.R2 software to process the data. First, selecting keyword in the Citespace software and entering the visual interface. Then, the clustering function is selected to perform the keyword co-occurrence network for cluster analysis. Finally, selecting the clustering results in the timeline view. Figure 2 shows the knowledge map of the green technology research keyword co-occurrence timeline in China.

In the timeline knowledge map, different horizontal lines represent different clustering results, and the same clustering results are displayed on the same horizontal

Table 1. Keywords burst of green technology's research frontiers in China.

\begin{tabular}{|c|c|c|}
\hline Keywords & Centrality & $\begin{array}{l}\text { The time } \\
\text { periods }\end{array}$ \\
\hline Technology innovation & 3.472 & 1994 to 2001 \\
\hline Green technology & 3.471 & 1994 to 1999 \\
\hline Industrial technology & 2.9943 & 1994 to 1999 \\
\hline Driving mechanism & 1.9916 & 1994 to 1999 \\
\hline Environment protection & 1.5738 & 1994 to 1999 \\
\hline Sustainable development & 4.8863 & 1994 to 2007 \\
\hline Ecological economics & 1.318 & 1999 to 2004 \\
\hline Sewage treatment & 1.6111 & 2000 to 2003 \\
\hline Green marketing & 2.8319 & 2001 to 2002 \\
\hline Innovation auditing & 1.8836 & 2001 to 2002 \\
\hline Green technology barrier & 1.9862 & 2002 to 2009 \\
\hline $\begin{array}{l}\text { Small and medium-sized enter- } \\
\text { prises }\end{array}$ & 1.5391 & 2002 to 2005 \\
\hline Global competitiveness & 1.5391 & 2002 to 2005 \\
\hline Circular economy & 6.955 & 2003 to 2008 \\
\hline Green management & 1.318 & 2003 to 2008 \\
\hline Scientific development concept & 1.8887 & 2004 to 2005 \\
\hline Cleaner production & 1.6574 & 2008 to 2010 \\
\hline Evolutionary game & 1.6968 & 2015 to 2017 \\
\hline Low-carbon city & 1.3386 & 2015 to 2017 \\
\hline Green technology investment & 1.3386 & 2015 to 2017 \\
\hline Low-carbon economy & 1.8887 & 2010 to 2011 \\
\hline Green patent & 1.4957 & 2010 to 2014 \\
\hline Green economy & 1.5494 & 2012 to 2014 \\
\hline Green technical efficiency & 1.7606 & 2013 to 2015 \\
\hline Technological diffusion & 1.6779 & 2013 to 2014 \\
\hline
\end{tabular}

line. Therefore, we can find that the evolutionary path of green technology research hotspots in China is that green technology, technological innovation and environmental protection have long been research hotspots. Moreover, green technology innovation and environmental regulation have also attracted the attention of scholars since 2000, and green technology advancement has become a research hotspot since 2006. Subsequently, ecological civilization and green patents have received the attention of scholars since 2009. Green technology innovation efficiency and green technology efficiency has become a hot spot since 2013. It is also worth mentioning that before 2015, sustainable development, circular economy and green marketing have also become hotspots of green technology research in China.

\section{Research Frontier}

In order to gain the research frontiers of green technology in China, we used the co-occurrence network analysis function of CiteSpace5.2.R2 software to process data. After selecting the keywords in Citespace software to enter the visual interface, the keywords burst of China's green technology research frontiers are selected by the burst detection function (Table 1). It can be found that the research frontier of green technology in China can be divided into three stages:

- The first stage is the budding stage of green technology research in China between 1994 and 2010. The early research frontier thoughts are based on sustainable development and scientific development concept and environment protection. The background of this period of research includes economics and circular economy, green marketing and green management. The research covers small and medium-sized enterprises, technology innovation, green technology, industrial technology and green technology barrier, and the research contents mainly include driving mechanism, sewage treatment, innovation auditing, global competitiveness and cleaner production.

- The second stage is the rapid growth stage of green technology research in China between 2010 and 2014. The keywords of research frontier are mainly low-carbon economy and green economy, green patent and green technical efficiency and technological diffusion.

- The third stage is the deepening stage of green technology research in China from 2015 to present. With the deepening of research, the frontier research methods of this period are mainly based on evolutionary game. The research object is mainly low-carbon city, and the research content is green technology investment. 
Table 2. Co-cited literature (Centrality top10).

\begin{tabular}{|c|c|c|c|c|c|}
\hline Frequency & Centrality & Author & Year & Title & Journal \\
\hline 1 & 0.16 & $\begin{array}{l}\text { CHUNG Y.H., FÄRE } \\
\text { R., GROSSKOPF S. }\end{array}$ & 1997 & $\begin{array}{l}\text { Productivity and Undesirable Outputs: A } \\
\text { Directional Distance Function Approach }\end{array}$ & $\begin{array}{c}\text { Journal of Environmental } \\
\text { Management }\end{array}$ \\
\hline 1 & 0.15 & $\begin{array}{l}\text { BROCK W.A., } \\
\text { TAYLOR M.S. }\end{array}$ & 2010 & The Green Solow model & $\begin{array}{l}\text { Journal of Economic } \\
\text { Growth }\end{array}$ \\
\hline 4 & 0.09 & BAI X., SONG,Y. & 2009 & $\begin{array}{l}\text { Environment Regulation, Technology } \\
\text { Innovation and Efficiency Improvement } \\
\text { of Chinese Thermal Power Industry }\end{array}$ & China Industrial Economics \\
\hline 1 & 0.09 & WANG E.C. & 2007 & $\begin{array}{c}\text { R\&D efficiency and economic performance: } \\
\text { A cross-country analysis using the stochastic } \\
\text { frontier approach }\end{array}$ & Journal of policy modeling \\
\hline 3 & 0.08 & TU Z. & 2008 & $\begin{array}{l}\text { The Coordination of Industrial Growth } \\
\text { with Environment and Resource }\end{array}$ & Economic Research Journal \\
\hline 3 & 0.08 & $\begin{array}{l}\text { GROSSMAN G.M., } \\
\text { KRUEGER A.B. }\end{array}$ & 1995 & Economic Growth and the Environment & $\begin{array}{l}\text { Quarterly Journal } \\
\text { of Economics }\end{array}$ \\
\hline 2 & 0.08 & $\begin{array}{l}\text { LANOIE P., PATRY } \\
\text { M., LAJEUNESSE R. }\end{array}$ & 2008 & $\begin{array}{l}\text { Environmental regulation and productivity: } \\
\text { testing the porter hypothesis }\end{array}$ & $\begin{array}{c}\text { Journal of Productivity } \\
\text { Analysis }\end{array}$ \\
\hline 3 & 0.07 & $\begin{array}{l}\text { WANG B., WU Y., } \\
\text { YAN P. }\end{array}$ & 2010 & $\begin{array}{l}\text { Environmental Efficiency } \\
\text { and Environmental Total Factor Productivity } \\
\text { Growth in China's Regional Economies }\end{array}$ & Economic Research Journal \\
\hline 1 & 0.07 & $\begin{array}{l}\text { BRUNNERMEIER } \\
\text { S.B., COHEN M.A. }\end{array}$ & 2003 & $\begin{array}{l}\text { Determinants of environmental innovation in } \\
\text { US manufacturing industries }\end{array}$ & $\begin{array}{c}\text { Economics } \\
\text { and Management }\end{array}$ \\
\hline 1 & 0.07 & $\begin{array}{l}\text { GALLAGHER K.S., } \\
\text { ANADON L.D., } \\
\text { KEMPENER R., } \\
\text { WILSON C. }\end{array}$ & 2011 & $\begin{array}{l}\text { Trends in investments in global } \\
\text { energy research, development, } \\
\text { and demonstration }\end{array}$ & $\begin{array}{l}\text { Wiley Interdisciplinary } \\
\text { Reviews: Climate Change }\end{array}$ \\
\hline
\end{tabular}

\section{Basic Knowledge}

In order to clarify the knowledge base of green technology research in China, which can be reflect by the co-cited collection of documents, this paper uses the co-citation analysis function of CiteSpace5.2.R2 software to process the data. In order to enter the visual interface after selecting the Cited Reference in the Citespace software, there is a result about co-citation of the green technology research literature in China (Tables 2 and 3), which can show that the knowledge base of green technology research in China is mainly composed of efficiency, the relationship between the environment and the economy, green technological innovation, environmental regulation and intellectual property.

Braun and Wield [26], the earliest scholars to study green technology, believe that green technology is a technology, process or product that reduces environmental pollution, raw materials and energy consumption. They also point out that various regulatory policies such as market regulation will affect the development of technology, and regulation is a technology policy that is an essential component. Yang and $\mathrm{Xu}$ [27] believe that green technology covering three levels of end management technology, cleaning process and green products can save resources and avoid or reduce environmental pollution.
First, efficiency. In order to measure the change of efficiency and technicality, Chung et al. [28] constructed a Malmquist-Luenberger index based on the directional distance function, which solved the problem of efficiency evaluation when considering environmental factors. Wang [29] found that research and development efficiency directly affects the country's progress and development prospects. Tu [30] pointed out that in order to achieve the coordinated development of industry and environment, it is necessary to increase the investment in independent research and development and technology introduction, and consummate the management of technical transformation costs. Wang et al. [31] found that environmental inefficiency mainly comes from excessive use of energy and excessive emissions of $\mathrm{SO}_{2}$ and $\mathrm{COD}$. Growth rate of total factor productivity of the environment is higher than that of the market. Zhang and Zhu [32] found that environmental factors are conducive to improving industrial enterprises' technological innovation efficiency.

Second, the relationship between the environment and the economy. In order to explain the impact of economic growth on the ecological environment, Grossman and Krueger [33] found that the impact of economic growth on the environment is an evolutionary process from the environmental deterioration stage in the initial stage of economic growth to the subsequent stage of environmental improvement, and the turning 
Table 3. Co-cited literature (Frequency top10).

\begin{tabular}{|c|c|c|c|c|c|}
\hline Frequency & Centrality & Author & Year & Title & Journal \\
\hline 11 & 0 & \begin{tabular}{|c|} 
ZHANG C., LU \\
Y., GUO L., YU T.
\end{tabular} & 2011 & $\begin{array}{l}\text { The Intensity of Environmental Regulation and } \\
\text { Technological Progress of Production }\end{array}$ & $\begin{array}{l}\text { Economic Research } \\
\text { Journal }\end{array}$ \\
\hline 8 & 0 & $\begin{array}{l}\text { JING W., } \\
\text { ZHANG L. }\end{array}$ & 2014 & $\begin{array}{c}\text { Environmental Regulation, Economic Open- } \\
\text { ing and China's Industrial Green Technology } \\
\text { Progress }\end{array}$ & $\begin{array}{l}\text { Economic Research } \\
\text { Journal }\end{array}$ \\
\hline 6 & 0 & $\begin{array}{l}\text { ZHANG J., } \\
\text { ZHU L. }\end{array}$ & 2012 & $\begin{array}{l}\text { Research on Technological Innovation } \\
\text { Efficiency of Industrial Enterprises Based on } \\
\text { Green Growth of Regions in China }\end{array}$ & $\begin{array}{l}\text { The Journal of } \\
\text { Quantitative \& } \\
\text { Technical Economics }\end{array}$ \\
\hline 6 & 0.01 & $\begin{array}{l}\text { XU S., HE Z., } \\
\text { LONG R. }\end{array}$ & 2012 & $\begin{array}{l}\text { The effects of environmental regulations on } \\
\text { enterprise green technology innovation }\end{array}$ & $\begin{array}{l}\text { Science Research } \\
\text { Management }\end{array}$ \\
\hline 6 & 0 & HE X. & 2010 & $\begin{array}{l}\text { From green technology to green patents } \\
\text {-Does this required a special patent system that } \\
\text { responds to climate change? }\end{array}$ & Intellectual Property \\
\hline 5 & 0 & $\begin{array}{l}\text { ACEMOGLU } \\
\text { D., AGHION H., } \\
\text { BURSZTYN L., } \\
\text { HEMOUS D. } \\
\end{array}$ & 2012 & $\begin{array}{c}\text { The Environment and Directed Technical } \\
\text { Change }\end{array}$ & $\begin{array}{l}\text { American Economic } \\
\text { Review }\end{array}$ \\
\hline 5 & 0.03 & $\begin{array}{l}\text { BRAUN E., } \\
\text { WIELD D. }\end{array}$ & 1994 & $\begin{array}{l}\text { Regulation as a means for the social control } \\
\text { of technology }\end{array}$ & $\begin{array}{l}\text { Technology Analysis \& } \\
\text { Strategic Management }\end{array}$ \\
\hline 5 & 0 & YANG F., XU Q. & 1998 & $\begin{array}{c}\text { Enterprise Green Technology Innovation } \\
\text { Research }\end{array}$ & China Soft Science \\
\hline 4 & 0.06 & $\begin{array}{l}\text { GE X., WANG J., } \\
\text { XUE B. }\end{array}$ & 2005 & $\begin{array}{l}\text { Research on the Countermeasures to Promote } \\
\text { Environmentally Sound Technology Innovation } \\
\text { in Small and Medium-sized Enterprises }\end{array}$ & $\begin{array}{l}\text { Science of Science and } \\
\text { Management of S.\& T. }\end{array}$ \\
\hline 4 & 0.09 & BAI X., SONG Y. & 2009 & $\begin{array}{l}\text { Environment Regulation, Technology } \\
\text { Innovation and Efficiency Improvement } \\
\text { of Chinese Thermal Power Industry }\end{array}$ & $\begin{array}{l}\text { China Industrial } \\
\text { Economics }\end{array}$ \\
\hline
\end{tabular}

point of this evolution caused some differences because of different pollutants. Brock and Taylor [34] studied the relationship between economic growth and the environment, finding that the environmental Kuznets curve in environmental economics is closely related to the Solow model in modern macroeconomics. Gallagher et al. [35] found that despite the large differences in the allocation of funds to different energy technologies in different countries, investments in fossil fuels and nuclear technology still dominate.

Third, green technological innovation. Ge et al. [36] believe that green technological innovation can be divided into two categories of green product innovation and green process innovation. $\mathrm{Xu}$ et al. [37] found that the sewage tax rate and the discharge permit price are positively correlated with the incentive level of the enterprise's green technological innovation.

Fourth, environmental regulation. Lanoie et al. [38] examined the Porter hypothesis, which showed that more stringent environmental enforcement may have a positive impact on firm performance through innovation incentives. Bai and Song [39] believe that environmental regulation has a technological innovation incentive effect on industry for taking China's thermal power industry as an example. Zhang et al. [40] believe that the improvement of corporate pollution control technology and the advancement of production technology require the rational formulation of government environmental regulation policies. Acemoglu et al. [41] found that environmental regulation can promote technological advances in low-emissions products, and the best policy involves both carbon taxes and research subsidies. Jing et al. [42] found that reasonable environmental regulation can transform the direction of technological progress and help Chinese industries to advance toward green technology.

Fifth, green technology and intellectual property. Under the objective reality of climate change, $\mathrm{He}$ (2010) [43] pointed out that a set of intellectual property systems covering the balance of green technology should be established. Brunnermeier and Cohen (2003) [44] found that there is a significant positive correlation between sewage charges and environmental patents.

Since implementing its economic reforms and opening to the world in 1978, China's economic level has continued to grow, and the level of productivity has made tremendous progress (Gong, 2015; Lau and Zheng, 2017) [45-46]. China has entered a new era where people not only demand improved material living standards, but their demands for living environment levels are also increasing. From the $15^{\text {th }}$ National Congress of the Communist Party of China in 1997 to the $19^{\text {th }}$ National Congress of the Communist Party of China in 2017, China's "Two centenary" goals have been 
mentioned many times in that the ultimate goal of the Chinese government is to build China into a powerful, democratic, civilized, harmonious and beautiful modern socialist power. Xi Jinping, president of the People's Republic of China, pointed out in the 19th National Congress of the Communist Party of China that the modernization we are building is the modernization of harmony between man and nature (Xinhua, 2017) [4]. In order to achieve these goals, China should implement the concept of green development in all aspects, especially in the production of enterprises.

Technology is one of the most important production factors of an enterprise that is related to both the core competitiveness of the enterprise and people's living environment. How can enterprises develop to maintain their core competitiveness? In the context of green development, Chinese companies should give priority to the use of green technology in the future. In essence, green technology is an innovative development of the company in the context of green development. This paper believes that we should adhere to green development, and enterprises should adopt green technology. In order to improve production efficiency, enterprises should take green development as their thought guide and adopt low-pollution and low-emission green technology in the process of research and development and the introduction of advanced technologies. In this way, the company not only achieves the purpose of improving production efficiency, but also protects the ecological environment, enhancing the public's impression of the enterprise.

In addition, the government should not only specify environmental regulations for enterprises, but also support qualified enterprises to apply for invention patents in the field of green technology, and support the application of well-qualified invention patents to enterprises' production links. Moreover, relevant departments can also set up a special fund and reward mechanism for green technology development, which is mainly used to support research institutes on green technology research and mobilize scholars' enthusiasm for green technology research.

\section{Conclusions}

The research methods used in this paper are bibliometrics and MKD. The 206 papers (1994 to 2017), mainly from the CSSCI database, were studied indepth by the age distribution characteristics, research hotspots, research frontiers and knowledge base. We arrived at the following main conclusions:

- The number of Chinese scholars' research on green technology shows an N-type upward trend, and will continue to rise in the future.

- The evolutionary path of China's green technology research hotspots is that green technology, technological innovation and environmental protection have long been research hotspots.
Green technological innovation and environmental regulation have also received the attention of scholars since 2000, and green technology advancement has been a research hotspot since 2006. Subsequently, ecological civilization and green patents have received the attention of scholars since 2009. Green technology innovation efficiency and green technical efficiency have been hotspots since 2013. It is also worth mentioning that before 2015, sustainable development, circular economy and green marketing have also become hotspots of green technology research in China.

- The frontiers of green technology research in China can be divided into three stages: germination, rapid growth and depth advancement. The first stage is the budding stage of green technology research in China between 1994 and 2010. The early research frontier thoughts are based on sustainable development and scientific development concept and environmental protection. The research background of this period includes economics and the circular economy, green marketing and green management. The research covers small and medium-sized enterprises, technological innovation, green technology, industrial technology and the green technology barrier. The research content mainly includes driving mechanisms, sewage treatment, innovation auditing, global competitiveness and cleaner production. The second stage is the rapid growth stage of green technology research in China between 2010 and 2014. The keywords of research frontier in this period are mainly low-carbon economy and green economy, green patent and green technical efficiency and technological diffusion. The third stage is the deepening stage of green technological research in China from 2015 to the present. With the deepening of research, the frontier research methods of this period are mainly based on an evolutionary game. The research object is mainly low-carbon city, and the research content is mainly green input.

- The knowledge base of green technology research in China is mainly composed of efficiency, the relationship between the environment and the economy, green technological innovation, environmental regulation and intellectual property.

There were some limitations in this research. The data we used were culled from CSSCI, which contains the literature representing the authority of Chinese social science research. However, the database only contains Chinese literature that only represents the views of Chinese researchers. In future research, the sample size range can be expanded by using SCI, SSCI and other databases as data sources.

\section{Acknowledgements}

This work was supported by the Special Funds of the National Social Science Fund of China (18VSJ038). 


\section{Conflict of Interest}

The authors declare no conflict of interest.

\section{References}

1. SARTAL A., LLACH J., VÁZQUEZ X.H., CASTRO R.D. How much does Lean Manufacturing need environmental and information technologies? Journal of Manufacturing Systems 45, 260, 2017.

2. KRUMINS J., KLAVINS M., KALNINA L. Fen peat in environmentally friendly technologies. Energy Procedia 147, 114, 2018.

3. CORIA J., KYRIAKOPOULOU E. Environmental policy, technology adoption and the size distribution of firms. Energy Economics 72, 470, 2018.

4. XINHUA. Full text of Xi Jinping's report at 19th CPC National Congress. http://www.xinhuanet.com//english/ special/2017-11/03/c_136725942.htm, (accessed on 3 November 2017).

5. LI X., DU J., LONG H. A Comparative Study of Chinese and Foreign Green Development from the Perspective of Mapping Knowledge Domains. Sustainability 10 (12), 4357, 2018.

6. LI X., DU J., LONG H. Green Development Behavior and Performance of Industrial Enterprises Based on Grounded Theory Study: Evidence from China. Sustainability $\mathbf{1 1}$ (15), 4133, 2019.

7. SHARMA M.M. Science and dividends in the practice of green technology: cleaner and greener is smarter. Clean Products and Processes 3 (1), 0002, 2001.

8. KING A., LENOX M. Exploring the Locus of Profitable Pollution Reduction. Management Science 48 (2), 289, 2002.

9. KUNAPATARAWONG R., MARTÍNEZ-ROS E. Towards green growth: How does green innovation affect employment? Research Policy 45 (6), 1218, 2016.

10. AKMAN I., MISHRA A. Sector diversity in Green Information Technology practices: Technology Acceptance Model perspective. Computers in Human Behavior 49, 477, 2015.

11. STUCKI T., WOERTER M. Intra-firm diffusion of green energy technologies and the choice of policy instruments. Journal of Cleaner Production 131, 545, 2016.

12. YIN S., LI B. Matching management of supply and demand of green building technologies based on a novel matching method with intuitionistic fuzzy sets. Journal of Cleaner Production 201, 748, 2018.

13. HARDIN-RAMANAN S., CHANG V., ISSA T. A Green Information Technology governance model for large Mauritian companies. Journal of Cleaner Production 198, 488, 2018.

14. BIRESSELIOGLU M.E., NILSEN M., DEMIR M.H., RØYRVIK J., KOKSVIK G. Examining the barriers and motivators affecting European decision-makers in the development of smart and green energy technologies. Journal of Cleaner Production 198, 417, 2018.

15. YANG W., PAN Y., MA J., ZHOU M., CHEN Z., ZHU W. Optimization on emission permit trading and green technology implementation under cap-and-trade scheme. Journal of Cleaner Production 194, 288, 2018.

16. BANSAL S. Choice and design of regulatory instruments in the presence of green consumers. Resource and Energy Economics 30 (3), 345, 2008
17. BI G., JIN M., LING L., YANG F. Environmental subsidy and the choice of green technology in the presence of green consumers. Annals of Operations Research 255 (12), 547,2016

18. STEFAN A., PAUL L., Does It Pay to Be Green? A Systematic Overview. Academy of Management Perspectives 22 (4), 45, 2008.

19. VALERO A., VALERO A., CALVO G., ORTEGO A. Material bottlenecks in the future development of green technologies. Renewable and Sustainable Energy Reviews 93, 178, 2018.

20. JIA X., DAI T., GUO X. Comprehensive exploration of urban health by bibliometric analysis: 35 years and 11,299 articles. Springer-Verlag New York, Inc, 2014.

21. LI W., ZHAO Y. Bibliometric analysis of global environmental assessment research in a 20 -year period. Environmental Impact Assessment Review 50, 158, 2015.

22. WANG B., PAN S.Y., KE R.Y., WANG K., WEI Y.M. Erratum to: An overview of climate change vulnerability: a bibliometric analysis based on Web of Science database. Natural Hazards 75 (S2) 301, 2015.

23. LI X., DU J., LONG H., Dynamic analysis of international green behavior from the perspective of the mapping knowledge domain. Environmental Science and Pollution Research, 26 (6), 6087, 2019.

24. SHIFFRIN R.M., BÖRNER K. Mapping knowledge domains. Proc Natl Acad Sci U S A 101 (1), 5183, 2004.

25. CHEN C. CiteSpace II: Detecting and visualizing emerging trends and transient patterns in scientific literature. John Wiley \& Sons, Inc., 359, 2006.

26. BRAUN E., WIELD D. Regulation as a means for the social control of technology. Technology Analysis \& Strategic Management 6 (3), 259, 1994.

27. YANG F., XU Q. Enterprise Green Technology Innovation Research. China Soft Science (3), 47, 1998 [In Chinese].

28. CHUNG Y.H., FÄRE R., GROSSKOPF S. Productivity and Undesirable Outputs: A Directional Distance Function Approach. Journal of Environmental Management 51 (3), 229, 1997.

29. WANG E.C. R\&D efficiency and economic performance: A cross-country analysis using the stochastic frontier approach. Journal of Policy Modeling 29 (2), 345, 2007.

30. TU Z. The Coordination of Industrial Growth with Environment and Resource. Economic Research Journal (2), 93, 2008 [In Chinese].

31. WANG B., WU Y., YAN P. Environmental Efficiency and Environmental Total Factor Productivity Growth in China's Regional Economies. Economic Research Journal 45 (5), 95, 2010 [In Chinese].

32. ZHANG J., ZHU L. Research on Technological Innovation Efficiency of Industrial Enterprises Based on Green Growth of Regions in China. The Journal of Quantitative \& Technical Economics 29 (2), 113, 2012 [In Chinese].

33. GROSSMAN G.M., KRUEGER A.B. Economic Growth and the Environment. Quarterly Journal of Economics, 110 (2), 353, 1995.

34. BROCK W.A., TAYLOR M.S. The Green Solow model. Journal of Economic Growth 15 (2), 127, 2010.

35. GALLAGHER K.S., ANADON L.D., KEMPENER R., WILSON C. Trends in investments in global energy research, development, and demonstration. Wiley Interdisciplinary Reviews: Climate Change 2 (3), 373, 2011.

36. GE X., WANG J., XUE B. Research on the Countermeasures to Promote Environmentally Sound Technology Innovation in Small and Medium-sized 
Enterprises. Science of Science and Management of S.\& T. (12), 87, 2005 [In Chinese].

37. XU S., HE Z., LONG R. The effects of environmental regulations on enterprise green technology innovation. Science Research Management 33 (6), 67, 2012 [In Chinese].

38. LANOIE P., PATRY M., LAJEUNESSE R. Environmental regulation and productivity: testing the porter hypothesis. Journal of Productivity Analysis 30 (2), 121, 2008.

39. BAI X., SONG Y. Environment Regulation, Technology Innovation and Efficiency Improvement of Chinese Thermal Power Industry. China Industrial Economics (8), 68, 2009 [In Chinese].

40. ZHANG C., LU Y., GUO L., YU T. The Intensity of Environmental Regulation and Technological Progress of Production. Economic Research Journal 46 (2), 113, 2011 [In Chinese].

41. ACEMOGLU D., AGHION H., BURSZTYN L., HEMOUS D. The Environment and Directed Technical Change. The American Economic Review, 102, 131, 2012.
42. JING W., ZHANG L. Environmental Regulation, Economic Opening and China's Industrial Green Technology Progress. Economic Research Journal, 49 (9), 34, 2014 [In Chinese].

43. HE X. From green technology to green patents - Does this required a special patent system that responds to climate change? Intellectual Property, 20 (1), 37, 2010 [In Chinese].

44. BRUNNERMEIER S.B., COHEN M.A. Determinants of environmental innovation in US manufacturing industries. Journal of Environmental Economics and Management, 45 (2), 278, 2003.

45. GONG B. Agricultural reforms and production in China: Changes in provincial production function and productivity in 1978-2015. Journal of Development Economics, 132, 18, 2018.

46. LAU L.J., ZHENG H. How much slack was there in the Chinese economy prior to its economic reform of 1978 ? China Economic Review, 45, 124, 2017. 
